BEATA PŁACZKIEWICZ (iD) https://orcid.org/0000-0003-0074-4096

Mazowiecka Uczelnia Publiczna w Płocku, Płock

The Mazovian State University in Płock e-mail: bplaczkiewicz@wp.pl

\title{
Inteligencja emocjonalna uczniów klas integracyjnych
}

\section{Emotional Intelligence of Students from Inclusive Classrooms}

\begin{abstract}
Nowadays emotional intelligence is seen as a set of characteristics essential for the effective functioning of a person. According to Salovey and Mayer's conception, it is perceived as a mental capability of using emotions properly. The author's own research was based on the Popular Questionnaire of Emotional Intelligence (PKIE) developed on the basis of this approach. A group of 68 nondisabled students from inclusive classrooms took part in the research. The results obtained by the respondents fall within the range of average results. There were significant differences in the statistics between females and males in the following aspects: the ability to control emotions, capability of understanding emotions and in the globally-defined emotional intelligence (the overall result). Furthermore, three profiles of results differing in quantity and quality in terms of the individual components of emotional intelligence were obtained following the statistical procedures. Among these profiles, the most significant was the one in which individual factors of emotional intelligence were developed at a lower level, except for empathy. However, wider research is necessary to come to any conclusions as regards the relation between the results of the research and inclusive education.
\end{abstract}

Keywords: emotions, emotional intelligence, development of emotional intelligence, adolescence, inclusive classroom, effectiveness of inclusive education

Słowa kluczowe: emocje, inteligencja emocjonalna, rozwój inteligencji emocjonalnej, adolescencja, klasa integracyjna, efektywność edukacji integracyjnej

\section{WPROWADZENIE}

Inteligencja emocjonalna spostrzegana jest współcześnie jako istotna dla efektywnego funkcjonowania jednostki. Choć na gruncie nauki nie wypracowano dotychczas ogólnie akceptowanej definicji czy sposobu konceptualizacji tego pojęcia, obserwuje się wciąż rosnący zakres analiz i badań w obszarze inteligencji emocjonalnej. Ponadto część prac ukierunkowanych jest na opracowanie skutecznych narzędzi diagnostycznych poziomu inteligencji emocjonalnej, co z kolei służy nie tylko celom poznawczym, ale również praktycznym.
Wiedza na temat struktury i roli inteligencji emocjonalnej może być użyteczna w wielu obszarach życia społecznego - w handlu, medycynie czy edukacji. Ostatni z wymienionych aspektów stanowić będzie przedmiot prezentowanego artykułu. Jednym z podmiotów czynnie zaangażowanych w proces rozwoju inteligencji emocjonalnej dzieci i młodzieży jest szkoła oraz zachodzące w niej procesy edukacyjne, wychowawcze i opiekuńcze. Jako teren badań wybrano szkołę integracyjną, w której wspólnie uczą się dzieci zdrowe oraz dzieci z niepełnosprawnościami. Jest to miejsce, w którym uwzględnianie i podążanie za zróżnicowanymi potrzebami 
i możliwościami każdego dziecka jest kwestią naturalną. W założeniach nauka w klasie integracyjnej powinna łączyć się w sposób szczególny z rozwijaniem kompetencji psychospołecznych i pożądanych postaw uczniów - treści te rozwinięto w dalszej części opracowania.

Celem niniejszego tekstu jest prezentacja wyników autorskiego projektu badawczego dotyczących poziomu inteligencji emocjonalnej pełnosprawnych uczniów klas integracyjnych oraz efektów wyodrębnienia grup różniących się profilem wyników w cząstkowo i globalnie rozumianej inteligencji emocjonalnej. Badanie inteligencji emocjonalnej w okresie rozwojowym (w tym przypadku adolescencji) pozwala $\mathrm{z}$ jednej strony na zdiagnozowanie mocnych stron jednostki lub przeciwnie - w przypadku niskiego poziomu - zaprojektowanie skutecznych strategii jej rozwijania. Zaprezentowane wyniki badań własnych mogą również stanowić impuls do dalszego eksplorowania kwestii efektywności kształcenia integracyjnego.

\section{INTELIGENCJA EMOCJONALNA W LITERATURZE PRZEDMIOTU}

Teoria wielu inteligencji przedstawiona została przez Howarda Gardnera w 1983 roku jako głos w dyskusji nad rozumieniem tego pojęcia i wyjście poza jego klasyczne ujęcie. W tej wielowymiarowej koncepcji ujęto między innymi inteligencję intrapersonalną związaną z umiejętnościami różnicowania własnych emocji oraz inteligencję interpersonalną dotyczącą zdolności do rozpoznawania i odróżniania uczuć, przekonań i intencji innych (Gardner, Kornhaber, Wake, 2001), co niewątpliwie dało impuls do rozwoju pojęcia inteligencji emocjonalnej . Sam termin pojawił się w literaturze psychologicznej znacznie wcześniej, bo już w latach 60. ubiegłego wieku (Matczak, Knopp, 2013). Joseph Ciarrochi, Amy Chan, Jane Bajgar (2001) na bazie metaanalizy ujęć różnych autorów, traktują inteligencję emocjonalną jako zdolność spostrzegania, rozumienia oraz zarządzania emocjami.

Tematyka inteligencji emocjonalnej została spopularyzowana przez Daniela Golemana
(1997), autora publikacji pod tymże tytułem, który przekonuje czytelnika o doniosłej, wręcz decydującej, roli inteligencji emocjonalnej dla powodzenia życiowego człowieka. Na gruncie literatury naukowej pojęcie inteligencji emocjonalnej zostało natomiast doprecyzowane przez Petera Saloveya i Johna D. Mayera (1990). Przybliżenie modelu zaproponowanego przez tych autorów wydaje się niezbędne, gdyż na ich koncepcji oparty jest Popularny Kwestionariusz Inteligencji Emocjonalnej (PKIE) wykorzystany w badaniach własnych. Model ów był wielokrotnie prezentowany i dyskutowany na gruncie literatury naukowej (np. Mayer, Salovey, 1997; Schutte i in., 1998; Brackett, Rivers, Salovey, 2011; Mayer, Caruso, Salovey, 2016).

Mayer i Salovey (1999) stoją na stanowisku, że właściwe zdefiniowanie inteligencji emocjonalnej wymaga uwzględnienia i zachowania istoty dwóch kluczowych pojęć: inteligencji i emocji, oraz ich wzajemnego oddziaływania. Traktują inteligencję emocjonalną jako zdolność umysłową pozwalającą ocenić stany emocjonalne. Mayer i Salovey zdefiniowali inteligencję emocjonalną jako

(...) umiejętność właściwej percepcji, oceny i wyrażania emocji, umiejętność dostępu do uczuć, zdolność ich generowania w momentach, gdy mogą wspomóc myślenie, umiejętność rozumienia emocji i zrozumienie wiedzy emocjonalnej oraz umiejętność regulowania emocji tak, by wspomagać rozwój emocjonalny i intelektualny (Mayer, Salovey, 1999, s. 34).

Wyodrębniono zatem cztery kluczowe umiejętności w porządku rozwojowym, rozpoczynając od prostej percepcji i ekspresji emocjonalnej, przechodząc do złożonych procesów związanych z refleksyjną i świadomą regulacją emocji. Autorzy podkreślają także, iż wskaźnik inteligencji emocjonalnej decyduje o tempie nabywania poszczególnych umiejętności - osoby o wysokiej inteligencji emocjonalnej sprawniej i szybciej przechodzą przez kolejne etapy nabywania umiejętności i przyswajają szerszy ich zakres (Mayer, Salovey, 1999). Wspomniane umiejętności kluczowe dla omawianego konstruktu zostaną syntetycznie scharakteryzowane. 
Pierwsza $\mathrm{z}$ nich to zdolność trafnego spostrzegania, oceniania i wyrażania emocji - bardziej szczegółowo określa zdolność do rozpoznawania emocji własnych i innych ludzi (także w kontekście przedmiotów, dzieł sztuki, opowieści czy muzyki), różnicowania wyrazu emocji, a także ich dokładnego wyrażania. Druga zdolność dotyczy wykorzystywania emocji w celu ułatwienia procesu myślenia - generowania, ekspresji i odczuwania emocji w procesie komunikowania uczuć, jak również posługiwania się nimi w procesach poznawczych. Emocje jako czynniki kierujące procesami uwagi, usprawniające zdolność osądu i pamięć dotyczącą uczuć, przyczyniają się do rozważania różnych perspektyw, aż w końcu wpływają na podejście do rozwiązywania problemów. Kolejna umiejętność cząstkowa dotyczy rozumienia i analizowania informacji emocjonalnej oraz posługiwania się wiedzą o emocjach - określa zdolność do nazywania emocji i rozumienia relacji między słowami a emocjami, zdolność do interpretacji emocjonalnego znaczenia relacji międzyludzkich czy rozumienia złożonych uczuć, a także zdolność przewidywania prawdopodobnych zmian stanów emocjonalnych. Z kolei ostatnia z omawianych - zdolność do regulowania emocji - sprzyja dobremu samopoczuciu oraz pobudzeniu rozwoju emocjonalnego i intelektualnego. Odnosi się do otwartości na przyjemne i nieprzyjemne uczucia oraz zdolności do świadomego zaangażowania się w emocje lub odłączenia się od nich w zależności od wyniku ich oceny. Na wyższym poziomie rozwoju określa między innymi zdolność do świadomego monitorowania emocji w odniesieniu do siebie i w relacjach z innymi, jak również zdolność do kontroli emocji własnych oraz innych ludzi (Mayer, Salovey, 1999; Salovey i in., 2005).

Omówiony wyżej model zdolnościowy nie jest jedynym, jaki wypracowano w obszarze inteligencji emocjonalnej (por. np. Brackett $\mathrm{i}$ in., 2011). Popularnością cieszą się również modele mieszane, których autorami są Daniel Goleman czy Reuven Bar-On (Sadowska, Brachowicz, 2008; Śmieja, Orzechowski, 2008). Katarzyna Knopp (2010), na podstawie przeglądu literatury naukowej, zwraca uwagę na liczne problemy związane z obszarem inteligencji emocjonalnej zarówno w aspekcie teoretycznym, jak i praktycznym, między innymi na wątpliwości terminologiczne i definicyjne, mały zakres badań tego konstruktu w kontekście roli doświadczeń społecznych, w szczególności środowiska rodzinnego i szkolnego w jego kształtowaniu, a nawet na kwestionowanie zasadności jego stosowania jako terminu naukowego (por. Przybylska, 2007; Matczak, Martowska, 2011; Matczak, Knopp, 2013). Także Magdalena Śmieja i Jarosław Orzechowski (2008) podkreślają, że sam sposób rozumienia konstruktu, jakim jest inteligencja emocjonalna, nie doczekał się jednoznacznego określenia - pojawiają się różne próby jego interpretowania w kategoriach umiejętności, zdolności, kompetencji czy cechy osobowości (np. definicja Garrido, 2012, s. 84).

Inteligencja emocjonalna odgrywa ważną rolę w różnych płaszczyznach życia (por. Salovey, Mayer, 1990; Ciarrochi, Chan, Bajgar, 2001; Brackett i in., 2011). Knopp (2010) na podstawie przeglądu literatury podkreśla jej znaczenie w osiągnięciach życiowych, sferze społecznej, poczuciu zadowolenia z życia czy emocjonalnym dobrostanie (por. np. Garrido, 2012). Na znaczenie emocji $\mathrm{w}$ radzeniu sobie z codziennymi wyzwaniami wskazują także Anna Matczak i Katarzyna Martowska (2011). Umiarkowanie optymistyczne stanowisko prezentują z kolei Salovey wraz ze współpracownikami (2005). Choć zgadzają się, że wyższy poziom inteligencji emocjonalnej łączy się z bardziej skutecznym radzeniem sobie z negatywnymi doświadczeniami emocjonalnymi i stresem oraz sprzyja skuteczności działania, to jednak akcentują, iż analizowany konstrukt nie jest odpowiedzią na wszelkie trudności doświadczane przez jednostkę.

Wyniki publikowane w literaturze światowej obejmujące osoby w okresie adolescencji dotyczą między innymi związku między inteligencją emocjonalną a poczuciem własnej skuteczności (Salavera, Usán, Jarie, 2017), depresją (Gomez-Baya i in., 2017), radzeniem sobie ze stresem oraz depresją i zaburzeniami zachowania (Davis, Humphrey, 2012), radzeniem sobie z wyzwaniami okresu adolescencji (Salavera, Usán, Teruel, 2019) czy osiągnięciami szkolnymi (Mancini i in., 2017). W wynikach niektórych badań ob- 
serwowano związek między innymi ze sposobem percepcji przez rówieśników i statusem w ich gronie, wskaźnikiem aktywności społecznej czy społecznych kompetencji. Ponadto w części badań potwierdzano pozytywny związek między empatią a zachowaniami prospołecznymi oraz kompetencjami emocjonalnymi i wsparciem społecznym. Mało jednoznaczne są natomiast doniesienia z zakresu relacji między inteligencją emocjonalną a satysfakcją $\mathrm{z}$ życia i zdrowiem fizycznym czy powodzeniem szkolnym. W niektórych badaniach udało się ustalić istnienie korelacji między inteligencją emocjonalną a dobrostanem psychicznym, na przykład większą skłonność u młodzieży o wysokiej inteligencji emocjonalnej do unikania zachowań ryzykownych, takich jak sięganie po używki (Knopp, 2006; 2010). Z kolei, jak podkreśla Carolyn Saarni:

(...) dzieci emocjonalnie kompetentne przystosowawczo i elastycznie kierują swymi działaniami, myślami i uczuciami w wielorakich kontekstach. Wykazują się skutecznością, pewnością siebie i poczuciem łączności z innymi, odnosząc się z poszanowaniem do ich doświadczeń emocjonalnych - radości, strachu czy smutku. To pozwala im również szanować samych siebie (Saarni, 1999, s. 116).

Analizie poddawane są także związki między inteligencją emocjonalną a płcią. Zdaniem części autorów kobiety lepiej radzą sobie z emocjami niż mężczyźni. Wnioski takie wyciągnęli między innymi Natalio Extremera, Pablo Fernández-Berrocal i Peter Salovey (2006) na podstawie badań 946 osób w wieku 16-58 lat. Wyższe wyniki w grupie kobiet osiągnęli także John D. Mayer, David R. Caruso i Peter Salovey (1999). Ciarrochi i współpracownicy (2001) na podstawie badań w grupie 131 osób w wieku 13-15 lat stwierdzili, że dziewczęta osiągają lepsze wyniki w ogólnym wskaźniku inteligencji emocjonalnej, jak również w zakresie spostrzegania emocji, regulowania emocji innych oraz w posługiwaniu się emocjami. Z kolei chłopcy lepiej radzą sobie z regulowaniem własnych emocji. Diego Gomez-Baya, Ramon Mendoza, Susana Paino, Margarida Gaspar de Matos
(2017), opierając się na metaanalizie badań, stwierdzili, że kobiety uzyskują wyższe wyniki w zakresie inteligencji emocjonalnej rozumianej jako zdolność, ale niższe $\mathrm{w}$ inteligencji emocjonalnej określanej przez samoocenę. Jako wyjaśnienie tego wyniku wskazuje się możliwe niedocenianie własnych możliwości emocjonalnych przez kobiety oraz ich przecenianie przez mężczyzn.

W kontekście rozwoju inteligencji emocjonalnej zazwyczaj wskazuje się na rolę zarówno czynników biologicznych, w szczególności temperamentalnych, jak i środowiskowych poziom zaspokojenia potrzeb fizycznych i psychicznych, oddziaływania wychowawcze, oczekiwania środowiska wobec zachowań dziecka czy dostarczane przez otoczenie wzorce zachowania (Zeidner, 2008; Knopp, 2010; Matczak, Knopp, 2013). Zdaniem Golemana (1997) rolę trenerów inteligencji emocjonalnej dziecka odgrywają przede wszystkim jego rodzice (por. także Michalska, 2004) przez uczenie takich umiejętności, jak różnicowanie odcieni emocji, rozpoznawanie emocji, kierowanie nimi, ich kontrolę, radzenie sobie z emocjami indukowanymi w relacjach interpersonalnych. Patrycja Michalska (2004), na bazie analizy literatury, stwierdza, że inteligencję emocjonalną można rozwijać w ciągu życia jednostki, mimo iż pewna jej część jest uwarunkowana konstytucjonalnie. Programy psychoedukacyjne w szkołach mogłyby się zatem przyczynić do rozwoju inteligencji emocjonalnej u uczniów, która u wielu z nich stanowi obszar deficytowy (por. także Przybyła-Basista, 2000). Podobne stanowisko reprezentują Mayer i Salovey (1999), twierdząc, że przynajmniej część umiejętności z całego zbioru określającego inteligencję emocjonalną można nabyć w drodze uczenia się, w czym kluczową rolę odgrywają osoby dorosłe - początkowo rodzice, zwłaszcza przez właściwe interakcje z dziećmi, następnie zaś nauczyciele, między innymi przez właściwie skonstruowane i realizowane programy nauczania (por. także Cejudo, López-Delgado, Losada, 2019; Qualter i in., 2007). Matczak i Knopp (2013), popierając ideę tworzenia programów stymulujących rozwój kompetencji emocjonalnej, zwracają uwagę na potrzebę szczególnej troski 
o ich jakość. Zgodnie z wynikami wielu badań inteligencja emocjonalna najsilniej rozwija się w dzieciństwie, okresie adolescencji i wczesnej dorosłości, uzyskując następnie pewien charakterystyczny dla jednostki poziom (Matczak, Knopp, 2013).

\section{EDUKACJA INTEGRACYJNA A PSYCHOSPOLECZNE FUNKCJONOWANIE UCZNIÓW}

Jednym z istotnych środowisk związanym zarówno z kształtowaniem, jak i wyrażaniem inteligencji emocjonalnej jest środowisko szkolne, także placówki integracyjnej. Jak podkreśla Zenon Gajdzica (2011), klasy integracyjne powstają przez włączanie do nich uczniów z różnymi niepełnosprawnościami, co oparte jest na tak zwanym modelu hamburskim. Skutkuje to wspólnym uczestnictwem uczniów pełnosprawnych i z niepełnosprawnością - we wszystkich lub wybranych - zajęciach edukacyjnych w ramach wspólnej przestrzeni, jaką stanowi klasa szkolna. Jolanta Lipińska (2000) wskazuje na duże zróżnicowanie w zakresie możliwości i potrzeb uczniów tworzących klasę integracyjną, zaś ich wspólna nauka i wychowanie stwarzają okazję do rozwijania pożądanych kompetencji społecznych. Aby jednak było to możliwe, niezbędne jest wsparcie i świadomość nauczycieli i wychowawców, których rolą jest uwzględnianie podmiotowości każdego dziecka jako uczestnika procesu integracji, stwarzanie warunków umożliwiających doświadczanie poczucia bezpieczeństwa i odnoszenia sukcesów na miarę indywidualnego potencjału. Danuta Al-Khamisy (2011) zwraca uwagę, że w edukacji integracyjnej dziecko kształtuje kompetencje społeczne, „uczy się współżycia z innymi i szacunku do inności”, integracja natomiast powinna sprzyjać rozwojowi między innymi empatii. W toku integracji dzieci powinny uczyć się wzajemnej tolerancji, rozumienia wzajemnych potrzeb, możliwości i ograniczeń oraz wzajemnej bezwarunkowej akceptacji.

Podobnie Danuta Apanel (2016) wśród istotnych celów funkcjonowania klas integracyjnych na poziomie szkoły podstawowej wymienia między innymi rozwijanie umiejętności interpersonalnych ważnych w życiu dorosłym, jak empatia, tolerancja czy umiejętność współpracy. Na podstawie dokonanego przeglądu badań wśród uwarunkowań powodzenia kształcenia integracyjnego wymienia się między innymi postawy wobec osób z niepełnosprawnością czy właściwe rozumienie ich potrzeb (por. Wiącek, Sękowski, 2007).

Wciąż jednak brakuje systematycznych badań w obszarze emocjonalno-społecznego funkcjonowania uczniów w ramach integracji w edukacji, na co wskazywali już Nienke M. Ruijs i Thea T.D. Peetsma (2009), dodając, że zazwyczaj dotyczą one statusu socjometrycznego i efektywności w zakresie relacji społecznych. Problematyczne jest również samo rozumienie takich pojęć, jak inkluzja, włączanie, integracja w obszarze edukacyjnym różnych krajów (por. także Kalambouka i in., 2007; Malmqvist, 2016), co utrudnia porównywanie wyników realizowanych badań naukowych. Ponadto badania zazwyczaj koncentrują się wokół efektów integracji w kontekście potrzeb i funkcjonowania dzieci ze specjalnymi potrzebami edukacyjnymi (por. np. Lindsay, 2007; Malmqvist, 2016; Szumski, Firkowska-Mankiewicz, 2010), przy większej koncentracji na aspektach edukacyjnych (Ruijs, Van der Veen, Peetsma, 2010). Jak wskazują Ruijs i Peetsma (2009), wśród publikowanych badań zazwyczaj uzyskuje się pozytywne czy neutralne efekty integracji. Analizy pokazują bardziej pozytywne postawy i mniej uprzedzeń wobec rówieśników ze specjalnymi potrzebami edukacyjnymi, większą akceptację, zrozumienie i tolerancję. Wątpliwości dotyczą jednak tego, czy przytoczone wyniki odnoszą się tylko do rówieśników z klasy czy ogólnie populacji osób ze specjalnymi potrzebami edukacyjnymi. Poza tym wskazywano, że owe postawy nie są tak pozytywne, jak wobec rówieśników zdrowych. Zbliżone rezultaty pokazuje przegląd badań, jakiego dokonali Afroditi Kalambouka, Peter Farrell, Alan Dyson, Ian Kaplan (2007) - większa tolerancja i wrażliwość, zmniejszenie lęku wyzwalanego ludzką różnorodnością, rozwój sprawności społecznych, wsparcie w budowaniu obrazu siebie jako korzyści z integracji dla uczniów zdrowych. Nieliczne pro- 
jekty pokazywały negatywne postawy uczniów zdrowych wobec ich rówieśników z deficytami rozwojowymi (por. także Ruijs, Van der Veen, Peetsma, 2010).

Wiącek i Sękowski (2007), na podstawie przeglądu badań publikowanych w polskiej literaturze psychologicznej, donoszą o pewnych pozytywnych efektach edukacji integracyjnej w sensie psychospołecznego funkcjonowania uczniów, nie zawsze jednak tak wyraźnych, jak zakładane w tej formie kształcenia. Z kolei Grzegorz Szumski (2011) powołuje się na wyniki badań Christiana Klicpera i Barbary Gasteiger Klicper, zgodnie z którymi uczniowie pełnosprawni w klasach integracyjnych w porównaniu z uczniami klas ogólnodostępnych wykazują wyższe kompetencje społeczne, co znajduje wyraz na przykład w niższym wskaźniku zachowań agresywnych czy wyższym poziomie zachowań prospołecznych. Podobnie Piotr Urbański, Agata Glapa i Renata Śleboda (2014), badając grupę uczniów ze szkół integracyjnych i masowych, stwierdzili, że dzieci przebywające z rówieśnikami z niepełnosprawnością wykazują wobec nich większą akceptację i otwartość (por. także Matyjas, 1997). Inne wyniki uzyskała Dorota Wiśniewska-Juszczak (2004), która w artykule „Czy szkoły integracyjne rozwijają kapitał społeczny dzieci?" analizuje poziom samooceny, zaufanie czy preferowany sposób nawiązywania i podtrzymywania kontaktów społecznych uczniów szkół integracyjnych i masowych. W wyniku przeprowadzonych badań nie stwierdzono jednak wyraźnych różnic między typami szkół w zakresie analizowanych czynników. I choć w konkluzji autorka stwierdza, że szkoła integracyjna nie przyczynia się do zwiększania kapitału społecznego dzieci, to jednak zwraca także uwagę na potrzebę realizowania dalszych badań w tym obszarze.

\section{PROBLEM}

Autorski projekt badawczy ma charakter wstępnej eksploracji problemu. $\mathrm{Na}$ etapie jego planowania i realizacji zmierzano do uzyskania odpowiedzi na następujące pytania badawcze: Jaki jest ogólny poziom inteligencji emocjo- nalnej oraz poszczególnych jej wymiarów w grupie pełnosprawnych uczniów klas integracyjnych? Czy płeć różnicuje poziom inteligencji emocjonalnej w grupie badanych? Czy populację osób badanych można podzielić na grupy różniące się profilem wyników w zakresie inteligencji emocjonalnej? Wyodrębnienie podgrup pozwala na głębsze poznanie badanej populacji, a tym samym na zindywidualizowanie i dostosowanie oddziaływań do potrzeb uczniów w zależności od profilu ich wyników w zakresie inteligencji emocjonalnej.

\section{METODA}

W celu uzyskania odpowiedzi na powyższe pytania na potrzeby badań własnych zastosowano Popularny Kwestionariusz Inteligencji Emocjonalnej (PKIE) w opracowaniu Anny Matczak, Aleksandry Jaworowskiej, Anny Ciechanowicz, Joanny Stańczak i Ewy Zalewskiej, oparty na modelu Saloveya i Mayera. Narzędzie zbudowane jest z 94 pozycji o charakterze samoopisowym, do których osoba badana odnosi się na skali 5-stopniowej (od „,zdecydowanie nie zgadzam się" - 1, do ,zdecydowanie się zgadzam" - 5). Część pozycji oblicza się na podstawie odwróconego klucza. Badanie narzędziem pozwala na obliczenie wyniku ogólnego oraz wyników w czterech skalach określających kolejno:

- Akceptowanie, wyrażanie i wykorzystywanie własnych emocji w działaniu (AKC);

- Empatię, czyli rozumienie i rozpoznawanie emocji innych ludzi (EMP);

- Kontrolę, także w sensie poznawczym nad własnymi emocjami (KON);

- Rozumienie i uświadamianie sobie własnych emocji (ROZ).

Normy stenowe opracowane zostały dla uczniów w wieku od 14 do 20 lat, z podziałem na płeć, oraz dla osób dorosłych w wieku od 18 do 71 lat.

Przeprowadzone procedury statystyczne pokazują, że PKIE jest rzetelnym i trafnym narzędziem diagnostycznym (wskaźnik rzetelności wyniku ogólnego w grupie uczniów oscyluje 
w graniach .90, z kolei w poszczególnych skalach wokół wartości .70; ponadto udowodniono wysokie współczynniki korelacji z wynikami Kwestionariusza Inteligencji Emocjonalnej INTE) (por. Jaworowska, Matczak, 2005).

Badaniami własnymi objęto grupę 68 pełnosprawnych uczniów klas integracyjnych, w tym 36 uczniów klas VIII szkoły podstawowej oraz 32 uczniów klas III gimnazjalnych, uczących się w szkole integracyjnej w średniej wielkości mieście. Średnia wieku osób badanych wyniosła $M=14.47$ ( $S D=.70$; zakres wieku 13-16 lat). W grupie badanych było 29 dziewcząt $(42.65 \%$ ogółu badanych) oraz 39 chłopców (57.35\% całości badanych).

Badania realizowano w formie grupowej. Kwestionariusze rozdano wszystkim uczniom oddziału klasowego, w którym prowadzono badania, przy czym do dalszych analiz zakwalifikowano dane uzyskane przez młodzież pełnosprawną. Badania przebiegały bez zakłóceń. Uczniowie chętnie przystąpili do badań, wykazywali jednak małe zainteresowanie uzyskanymi wynikami. Wszystkie kwestionariusze uzupełniane przez osoby badane były kompletne.

\section{WYNIKI}

Analiza wyników badań własnych przebiegała na kilku etapach. W pierwszej kolejności zestawiono wyniki surowe i wystandaryzowane uzyskane w skalach Popularnego Kwestionariusza Inteligencji Emocjonalnej przez całą grupę badanych uczniów $(\mathrm{N}=68)$. Następnie porównano wyniki średnie chłopców i dziewcząt w poszczególnych skalach narzędzia za pomoca testu $t$-Studenta.

W kolejnym etapie opisane zostały trzy grupy (wyodrębnione poprzez analizę skupień metodą $k$-średnich), z których każda reprezentuje odmienny profil wyników. Grupy zostały poddane analizie ilościowej i jakościowej ukierunkowanej na uchwycenie specyfiki każdej z nich. Obliczeń dokonano, korzystając z pakietu statystycznego STATICTICA 13.

W tabeli 1 umieszczono wyniki surowe oraz wyniki przeliczone w skali stenowej uczniów szkoły integracyjnej.

Dane zawarte w powyższej tabeli pokazują, iż wyniki średnie badanych uczniów $(N=68)$ należy zinterpretować jako przeciętne zarówno w cząstkowo, jak i globalnie rozumianej inteligencji emocjonalnej mierzonej Popularnym Kwestionariuszem Inteligencji Emocjonalnej. Najwyższy wynik dotyczy skali określającej zdolność do kontrolowania, także poznawczego własnych emocji (KON), najniższy zaś zdolności do akceptacji, wyrażania i wykorzystywania własnych emocji w działaniu (AKC).

W kolejnej tabeli zestawiono wyniki surowe (cząstkowe i wynik ogólny) uzyskane przez grupę badanych z podziałem na płeć oraz wyniki testu istotności różnic między średnimi wynikami w poszczególnych skalach oraz w wyniku ogólnym.

Dane zestawione w tabeli 2 pokazują istotne statystycznie różnice między chłopcami i dziew-

Tabela 1. Średnie wyników $(M)$, odchylenia standardowe $(S D)$, wartości minimalne (Min) oraz maksymalne (Max) w skalach Popularnego Kwestionariusza Inteligencji Emocjonalnej uzyskane przez badanych uczniów $(N=68)$

\begin{tabular}{|c|c|c|c|c|c|c|c|c|}
\hline \multirow{2}{*}{$\begin{array}{c}\text { Wymiary } \\
\text { inteligencji } \\
\text { emocjonalnej }\end{array}$} & \multicolumn{4}{|c|}{ Wyniki surowe } & \multicolumn{3}{|c|}{ Wyniki standardowe (skala stenowa) } \\
\cline { 2 - 9 } & Min & Max & $M$ & $S D$ & Min & Max & $M$ & $S D$ \\
\hline$A K C$ & 26 & 75 & $\mathbf{5 2 . 5 3}$ & 9.34 & 1 & 10 & $\mathbf{5 . 1 3}$ & 2.21 \\
\hline$E M P$ & 18 & 90 & $\mathbf{6 9 . 0 7}$ & 10.18 & 1 & 10 & $\mathbf{5 . 6 6}$ & 1.97 \\
\hline$K O N$ & 16 & 51 & $\mathbf{3 3 . 3 1}$ & 8.28 & 1 & 10 & $\mathbf{6 . 0 6}$ & 2.30 \\
\hline$R O Z$ & 15 & 49 & $\mathbf{3 2 . 6 5}$ & 7.68 & 1 & 10 & $\mathbf{5 . 9 4}$ & 2.27 \\
\hline$W O$ & 26 & 423 & $\mathbf{3 3 5 , 9 3}$ & 36.25 & 1 & 10 & $\mathbf{5 . 9 6}$ & 2.28 \\
\hline
\end{tabular}


Tabela 2. Wyniki surowe dziewcząt i chłopców wraz z porównaniem średnich testem $t$-Studenta

\begin{tabular}{|c|c|c|c|c|c|}
\hline $\begin{array}{c}\text { Wymiary inteligencji } \\
\text { emocjonalnej }\end{array}$ & $\begin{array}{c}\boldsymbol{M} \\
\text { (wynik średni) } \\
\text { dziewcząt }\end{array}$ & $\begin{array}{c}\text { M } \\
\text { (wynik średni) } \\
\text { chłopców }\end{array}$ & $\mathbf{t}$ & df & $\mathbf{p}$ \\
\hline$A K C$ & 50.14 & 54.31 & -1.85 & 66 & .068 \\
\hline$E M P$ & 70.76 & 67.82 & 1.18 & 66 & .242 \\
\hline$K O N$ & 28.24 & 37.07 & -5.10 & 66 & $\mathbf{. 0 0 1}$ \\
\hline$R O Z$ & 29.24 & 35.18 & -3.39 & 66 & $\mathbf{. 0 0 1}$ \\
\hline$W O$ & 325.55 & 343.64 & -2.09 & 66 & $\mathbf{. 0 4 1}$ \\
\hline
\end{tabular}

czętami w dwóch skalach Popularnego Kwestionariusza Inteligencji Emocjonalnej, a mianowicie w skali badającej zdolność do kontrolowania, także poznawczego własnych emocji (KON) oraz w skali diagnozującej zdolność do rozumienia i uświadamiania sobie własnych emocji (ROZ), jak również w globalnie rozumianej inteligencji emocjonalnej (WO). We wszystkich wymienionych wskaźnikach chłopcy uzyskali wyniki istotnie wyższe niż dziewczęta. Płeć nie różnicuje wyników w skali określającej zdolność do akceptowania, wyrażania i wykorzystywania własnych emocji w działaniu (AKC) - jedynie tendencja statystyczna oraz w skali zdolności do empatii (EMP).

W dalszym etapie realizowanego programu badań wyodrębniono trzy profile wyników różniących się nasileniem poszczególnych składowych inteligencji emocjonalnej oraz globalnie rozumianą inteligencją emocjonalną. Opierano się na wynikach wystandaryzowanych wyrażonych za pomocą skali stenowej. Wyniki analiz zestawiono $\mathrm{w}$ tabeli 3 oraz zobrazowano na wykresie 1.

Tabela 3. Porównanie grup w zakresie wyników średnich w skalach Popularnego Kwestionariusza Inteligencji Emocjonalnej

\begin{tabular}{|c|c|c|c|c|c|}
\hline \multirow{2}{*}{$\begin{array}{l}\text { Wymiary inteligencji } \\
\text { emocjonalnej }\end{array}$} & \multirow{2}{*}{$\begin{array}{c}\text { Grupa } 1 \\
N=\mathbf{2 8}\end{array}$} & \multirow{2}{*}{$\begin{array}{c}\text { Grupa } 2 \\
N=23\end{array}$} & \multirow{2}{*}{$\begin{array}{c}\text { Grupa } 3 \\
N=17\end{array}$} & \multicolumn{2}{|c|}{$\begin{array}{l}\text { Różnice } \\
\text { (ANOVA) }\end{array}$} \\
\hline & & & & $F$ & $p$ \\
\hline \multirow{2}{*}{$\begin{array}{l}A K C \mathrm{M} \\
\mathrm{SD}\end{array}$} & 4.82 & 3.65 & 7.65 & \multirow{2}{*}{31.22} & \multirow{2}{*}{.001} \\
\hline & 1.61 & 1.70 & 1.46 & & \\
\hline \multirow{2}{*}{$\begin{array}{l}E M P \mathrm{M} \\
\mathrm{SD}\end{array}$} & 4.75 & 5.35 & 7.59 & \multirow{2}{*}{16.89} & \multirow{2}{*}{.001} \\
\hline & 1.82 & 1.61 & 1.23 & & \\
\hline \multirow{2}{*}{$\begin{array}{l}K O N \mathrm{M} \\
\mathrm{SD}\end{array}$} & 7.36 & 3.39 & 7.53 & \multirow{2}{*}{74.42} & \multirow{2}{*}{.001} \\
\hline & 1.10 & 1.37 & 1.46 & & \\
\hline \multirow{2}{*}{$\begin{array}{l}R O Z \mathrm{M} \\
\mathrm{SD}\end{array}$} & 6.43 & 3.83 & 8.00 & \multirow{2}{*}{35.95} & \multirow{2}{*}{.001} \\
\hline & 1.53 & 1.67 & 1.58 & & \\
\hline \multirow{2}{*}{$\begin{array}{l}\text { WO M } \\
\mathrm{SD}\end{array}$} & 6.04 & 3.96 & 8,53 & \multirow{2}{*}{46.80} & \multirow{2}{*}{.001} \\
\hline & 1.23 & 1.87 & 1.23 & & \\
\hline
\end{tabular}




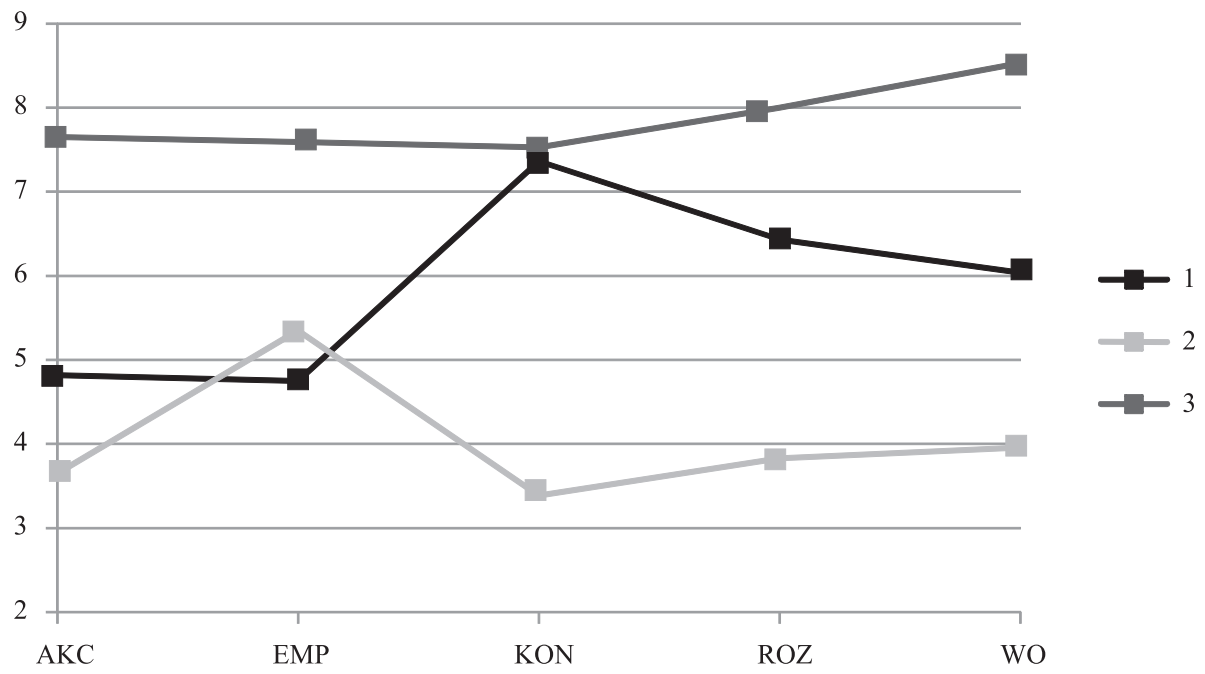

Wykres 1. Średnie wyniki w skalach Popularnego Kwestionariusza Inteligencji Emocjonalnej uzyskane przez trzy grupy badanych uczniów szkoły integracyjnej

Dane zaprezentowane w tabeli 3 oraz przedstawione na wykresie pokazują występowanie istotnych statystycznie różnic (ANOVA) pomiędzy trzema wyodrębnionymi grupami uczniów w zakresie średnich wyników w skalach Popularnego Kwestionariusza Inteligencji Emocjonalnej. Wyniki potwierdzają zróżnicowanie grup w poszczególnych obszarach inteligencji emocjonalnej $(p<.001)$.

Poniżej dokonana zostanie syntetyczna charakterystyka wyodrębnionych grup:

Grupa 1 - uczniowie o przeciętnej ogólnej inteligencji emocjonalnej, przy rozwiniętych zdolnościach do kontroli emocji i ich rozumienia

W skład pierwszej, najliczniej reprezentowanej grupy weszło łącznie 28 badanych uczniów, co stanowi $41.18 \%$ całości badanych (18 chłopców, czyli 46.15\% ogółu badanych chłopców oraz 10 dziewcząt, czyli $34.48 \%$ ogółu badanych dziewcząt).

W wynikach uzyskanych przez tę grupę uczniów zaznacza się przewaga zdolności do właściwego rozumienia i kontrolowania doznań emocjonalnych nad ich akceptacją oraz zdolnością do empatii. Grupę charakteryzuje przeciętny poziom inteligencji emocjonalnej ujmowanej globalnie.

Grupa 2 - uczniowie o obniżonej ogólnej inteligencji emocjonalnej, przy dobrej empatii.
Grupa ta utworzona została przez 23 badanych, czyli $33.82 \%$ całości (14 dziewcząt, czyli $48.28 \%$ ogółu badanych dziewcząt oraz 9 chłopców, czyli $23.08 \%$ ogółu badanych chłopców). Uczniowie z tej grupy uzyskali obniżony wynik ogólny, jak również niskie wyniki w poszczególnych skalach Popularnego Kwestionariusza Inteligencji Emocjonalnej, z wyjątkiem skali diagnozującej empatię, która kształtuje się u tych uczniów na poziomie przeciętnym.

Uczniów reprezentujących grupę drugą charakteryzuje obniżony poziom ogólnej inteligencji emocjonalnej. Na niskim poziomie kształtuje się zdolność wykorzystywania emocji przy radzeniu sobie z problemami. Uczniowie ci prezentują niską świadomość doświadczanych emocji, słabo rozumieją ich przyczyny i możliwe skutki, mają trudności z wyrażaniem emocji $\mathrm{i}$ ich kontrolą. $\mathrm{Z}$ drugiej strony dobrze rozpoznają i rozumieją emocje doświadczane przez innych i rozumieją ich potrzeby emocjonalne.

Grupa 3 - uczniowie o wysokiej ogólnej inteligencji emocjonalnej

W skład tej najmniej licznej grupy weszło 17 uczniów, co stanowi 25\% całości badanych (5 dziewcząt, czyli 17.24\% ogółu badanych dziewcząt oraz 12 chłopców, czyli 30.77\% ogółu badanych chłopców). Uzyskali oni wysokie wyniki we wszystkich skalach kwestionariu- 
sza - wszystkie na zbliżonym poziomie oraz wysoki wynik ogólny.

Uczniów tych charakteryzuje wysoka inteligencja emocjonalna. Uczniowie ci mają świadomość doświadczanych emocji, rozumieją ich przyczyny i skutki, potrafią je ujawniać, przy czym jednocześnie sprawnie przebiegają u nich procesy kontroli emocjonalnej, adekwatnie do wymagań konkretnej sytuacji. Nie doświadczają trudności z rozpoznawaniem i rozumieniem emocji doświadczanych przez innych czy rozumieniem ich potrzeb emocjonalnych.

\section{DYSKUSJA}

Prezentowany projekt badawczy dotyczył inteligencji emocjonalnej pełnosprawnych uczniów klas integracyjnych. Do badań zakwalifikowano grupę 68 uczniów, których zdiagnozowano $P_{o-}$ pularnym Kwestionariuszem Inteligencji Emocjonalnej (PKIE). Analiza ilościowa i jakościowa zebranego materiału pozwoliła na uzyskanie odpowiedzi na postawione pytania badawcze.

Średnie wyniki dla badanej populacji mieszczą się w ramach wyników przeciętnych. Uzyskano natomiast istotne statystycznie różnice między chłopcami i dziewczętami w zakresie zdolności do kontrolowania emocji oraz zdolności ich rozumienia. Płeć różnicuje także wynik globalny w inteligencji emocjonalnej. Chłopcy są zatem wyraźnie skuteczniejsi w sterowaniu własnymi emocjami, kierowaniu ich przebiegiem czy wyciszaniu emocji niepożądanych. W istotnie wyższym stopniu niż dziewczęta rozumieją własne emocje, łatwiej je nazywają czy różnicują ich intensywność. Mają istotnie większą wiedzę na temat czynników, które doprowadziły do wystąpienia u nich określonych emocji. $\mathrm{Na}$ podobnym poziomie u chłopców i dziewcząt kształtuje się z kolei zdolność odczytywania i rozumienia zachowań, emocjonalnych przeżyć czy intencji innych osób podobnie oraz zdolność adekwatnego okazywania różnych emocji. Zgodnie $\mathrm{z}$ danymi zamieszczonymi w publikacjach naukowych, różnic międzypłciowych w zakresie inteligencji emocjonalnej poszukuje się między innymi w uwarunkowaniach neurobiologicznych oraz odmiennych oddziaływaniach socjalizacyjnych (por. Matczak, Knopp, 2013). Kobiety spostrzegane są jako skuteczniejsze w obszarze emocjonalnym niż mężczyźni (por. np. Extremera i in., 2006; Mayer i in., 1999), co nie jest zgodne z wynikami badań autorskich. Pokrywają się one natomiast jedynie częściowo $\mathrm{z}$ rezultatami, o których donoszą Ciarrochi i współpracownicy (2001), zgodnie z którymi chłopcy lepiej radzą sobie z regulowaniem własnych emocji. Należy jednak wziąć pod uwagę metodę diagnozowania inteligencji emocjonalnej-badania własne oparto na samoopisie. Jak wskazują Gomez-Baya i współautorzy (2017), chłopcy uzyskują wyższe wyniki od dziewcząt w inteligencji emocjonalnej określonej na bazie samooceny, co można thumaczyć ich tendencją do przeceniania własnych możliwości emocjonalnych. Z kolei chłopcy, którzy weszli do próby normalizacyjnej podczas prac nad konstrukcją Popularnego Kwestionariusza Inteligencji Emocjonalnej, uzyskali istotnie wyższe wyniki w skalach rozumienia oraz kontroli emocjonalnej, ale istotnie niższe od dziewcząt w skali empatii. Ponadto płeć nie różnicowała ogólnego poziomu inteligencji emocjonalnej (por. Jaworowska, Matczak, 2005). Zatem prezentowane wyniki badań własnych jedynie częściowo pokrywają się z wynikami próby normalizacyjnej. Wyciąganie daleko idących wniosków może być jednak mylne, gdyż próby te różnią się między sobą. W badaniach własnych wzięła udział mniej liczba grupa uczniów, w której przeważali chłopcy, zaś średnia wieku wyniosła 14.47 (w liczniejszej próbie normalizacyjnej znaleźli się uczniowie szkół gimnazjalnych i ponadgimnazjalnych, średnia wieku wyniosła 16.58 , przeważała płeć żeńska).

W przeprowadzonych badaniach własnych dokonano także zabiegu pogrupowania osób badanych, mając na uwadze wyniki uzyskane w Popularnym Kwestionariuszu Inteligencji Emocjonalnej. Wyniki sklasyfikowano w trzy grupy: uczniów o przeciętnej inteligencji emocjonalnej przy rozwiniętych umiejętnościach kontroli emocji i ich rozumienia, uczniów o obniżonej inteligencji emocjonalnej przy dobrej empatii oraz uczniów o wysokiej inteligencji 
emocjonalnej. Uczniowie $\mathrm{z}$ grupy pierwszej prezentują szczególnie dobrze - na tle innych umiejętności - rozwiniętą zdolność kontroli, również w aspekcie poznawczym, własnych emocji. Potrafią sprawnie kierować przebiegiem emocji, nie dopuszczają do sytuacji zbyt silnego pobudzenia, potrafią efektywnie wyciszać niepożądane emocje. Wyraz emocji jest dostosowany do wymagań sytuacji. Świadomość w zakresie powyższych zdolności u osób badanych sprzyja bardziej efektywnemu działaniu. Ponadto badani z tej grupy dobrze rozumieją i uświadamiają sobie własne emocje. Ich zdolność nazywania emocji, rozróżniania poziomu intensywności emocji, świadomość ich przyczyn także jest dobrze rozwinięta. Na tle opisanych zdolności, słabiej jest rozwinięta u tych uczniów umiejętność rozumienia zachowań, emocji czy intencji innych osób oraz zdolność akceptacji, wyrażania i wykorzystywania w działaniu własnych doznań emocjonalnych.

Badane dziewczęta i chłopcy należący do grupy drugiej mają trudności z akceptowaniem doświadczanych emocji i ich ekspresją, mogą wykazywać tendencję do ich thumienia czy udawania emocji, które się w nich nie pojawiają. Może to skutkować trudnościami w odczytaniu ich właściwego stanu emocjonalnego przez osoby z otoczenia. Uczniowie ci doświadczają trudności w uczeniu się na podstawie własnych doświadczeń emocjonalnych. Są mało skuteczni w kontroli emocji, problemy może sprawiać im wyciszanie niepożądanych emocji oraz wzbudzanie pozytywnych stanów emocjonalnych. Są mało elastyczni w dostosowywaniu emocji do konkretnych sytuacji. Słabo rozumieją własne emocje, mają trudności w ich nazywaniu i różnicowaniu ich intensywności. Wykazują małą wiedzę na temat przyczyn doświadczanych emocji. Na tle tych wyraźnych trudności z akceptowaniem, wyrażaniem, kontrolowaniem czy rozumieniem własnego stanu emocjonalnego, dobrze rozumieją zachowania innych ludzi, przeżywane przez nich emocje oraz intencje, jakimi się kierują. Mają przeciętną świadomość tego, jakie emocje mogą wzbudzać w innych ludziach oraz potrafią całkiem dobrze dostrzegać w zachowaniach innych ludzi istotne niuanse.
Uczniowie z grupy trzeciej potrafią sprawnie posługiwać się własnymi emocjami przy rozwiązywaniu problemów. W pełni akceptują pojawiające się w nich emocje, wyrażają zarówno te pozytywne, jak i negatywne, bez tłumienia czy udawania. Dzięki temu inni ludzie są w stanie właściwie reagować na ich stany emocjonalne. Mają świadomość, że dzięki emocjom dowiadują się więcej na temat własnej osoby i otaczającej rzeczywistości, wyciągają wnioski z doświadczeń emocjonalnych, co przekłada się na skuteczne działanie. Ponadto uczniowie o wysokiej inteligencji emocjonalnej właściwie rozumieją zachowania innych ludzi i ich intencje. Potrafią postawić się w sytuacji innych osób i mają świadomość tego, jakie emocje $u$ innych mogą wywołać ich zachowania. Z kolei wysoki wynik w skali kontroli emocjonalnej wskazuje na bardzo dobrą zdolność do sterowania własnymi emocjami, w tym sprawne wyciszane niepożądanych emocji oraz generowanie pożądanych. Uczniowie ci potrafią dostosować sposób i stopień wyrazu emocji do wymagań konkretnej sytuacji. Mając świadomość znaczenia stanów emocjonalnych dla skutecznego realizowania działań, stosują tę wiedzę w praktyce. Równie wysoki wynik badani uzyskali w ostatniej ze skal. Wskazuje to na bardzo dobre rozumienie aktualnych emocji, wysoko rozwiniętą zdolność ich nazywania oraz rozróżniania ich intensywności. Poza tym uczniowie ci mają wiedzę na temat źródła doświadczanych przez nich emocji.

Także tutaj wyniki częściowo pokrywają się z uzyskanymi przez badanych z próby normalizacyjnej (por. Jaworowska, Matczak, 2005), nie sposób jednak pominąć między innymi różnic w liczbie skupień (w próbie normalizacyjnej wyodrębniono cztery profile wyników, na co pozwoliła liczniejsza reprezentacja badanych). W kontekście podobieństw w obu badaniach wyodrębniono grupę uczniów o wysokich wynikach w poszczególnych skalach Kwestionariusza oraz grupę, określoną jako posiadającą „strategiczną" inteligencję emocjonalną, to jest wyższe wyniki w skalach rozumienia i kontroli emocji, przy niższych w skalach akceptacji, nazywania i wyrażania emocji oraz empatii (por. Jaworowska, Matczak, 2005). Co cieka- 
we, w badaniach własnych wyodrębniono profil wyników, który nie pokrywa się z profilami z próby normalizacyjnej. W skład tej grupy weszli uczniowie o niskich wynikach w poszczególnych skalach inteligencji emocjonalnej, z wyjątkiem empatii, kształtującej się na poziomie przeciętnym.

Mając na uwadze rezultaty autorskiego projektu badawczego oraz założenia idei kształcenia integracyjnego (por. np. Lipińska, 2000; Al-Khamisy, 2011; Apanel, 2016) można było oczekiwać wyższych wyników grupy badanych, które kształtują się na poziomie przeciętnym. Efektywność integracji w edukacji w kontekście psychospołecznego funkcjonowania uczniów nie spotkała się dotychczas z jednoznaczną oceną, a publikowane projekty badawcze pokazują różne wyniki w tym zakresie, zazwyczaj jednak pozytywne lub neutralne (por. np. Kalambouka i in., 2007; Wiącek, Sękowski, 2007; Ruijs, Peetsma, 2009; Urbański, Glapa, Śleboda, 2014). Więcej informacji o grupie badanych uzyskano dzięki wyodrębnieniu podgrup. Zainteresowanie budzą właściwie dwie grupy - utworzona przez uczniów o wysokich wynikach w poszczególnych składowych inteligencji emocjonalnej oraz w wyniku ogólnym, oraz grupa uczniów o przeciętnej empatii z obniżonymi wynikami w pozostałych skalach i globalnej inteligencji emocjonalnej. Zachodzi pytanie, czy taki układ wyników może być związany z edukacją w szkole integracyjnej. Na tle deficytowych wyników w zakresie inteligencji emocjonalnej empatia stanowiłaby efekt procesu integracji, który łączy się z funkcjonowaniem w środowisku osób o mocno zróżnicowanych możliwościach psychofizycznych. Wyciąganie takich wniosków należy jednak czynić z dużą ostrożnością, a weryfikacja tej obserwacji wymaga przeprowadzenia bardziej pogłębionych, szerszych zakresowo i ilościowo badań.

Uzyskane wyniki badań własnych mają również wartość z perspektywy psychologii rozwojowej i wychowawczej. Dokonane pogrupowanie osób badanych pokazuje duże zróżnicowanie rozwojowe pod względem inteligencji emocjonalnej badanej populacji młodzieży szkolnej uczącej się w placówce integracyjnej. Inteligencja emocjonalna jest traktowana jako zbiór zdolności, które można rozwijać w toku życia jednostki. Jak wskazywano we wprowadzeniu do niniejszego tekstu szczególne znaczenie w tym kontekście mają właściwe oddziaływania ważnych wychowawczo środowisk - rodzinnego i szkolnego (por. np. Zeidner, 2008; Knopp, 2010). Analizując uzyskane profile wyników, na tle młodzieży o rozwiniętej inteligencji emocjonalnej wyłania się także grupa, która wymaga intensywnego wsparcia w postaci na przykład objęcia programem stymulującym rozwój wybranych obszarów inteligencji emocjonalnej, jak zdolność do akceptacji doświadczanych emocji, ich rozumienia czy kontrolowania. Warto także opracować szkolenia dla rodziców ukierunkowane na zwiększanie świadomości ich roli w kształtowaniu inteligencji emocjonalnej swoich dzieci oraz pokazanie praktycznych sposobów realizacji tego celu. Analiza literatury pokazuje bowiem, że młodzież znajduje się $\mathrm{w}$ wieku, w którym poziom inteligencji emocjonalnej może jeszcze podlegać zmianom rozwojowym (por. Matczak, Knopp, 2013).

Podsumowując, przeprowadzone badania posiadają pewne ograniczenia, między innymi diagnozie poddano uczniów z jednej szkoły integracyjnej, ponadto przy mało licznej grupie osób badanych trudno o generalizację uzyskanych wyników. Dodatkowo eksploracje prowadzono jedynie w grupie pełnosprawnych uczniów klas integracyjnych, bez uwzględnienia grupy kontrolnej, czyli uczniów klas masowych (stanowi to przedmiot osobnego artykułu). Przeprowadzone badania traktuję jako wstępną eksplorację problemu inteligencji emocjonalnej pełnosprawnych uczniów klas integracyjnych oraz podstawę do pogłębiania dotychczasowych pytań, stawiania kolejnych i podejmowania dalszych poszukiwań badawczych, także z wykorzystaniem innych niż oparte na samoopisie metod diagnostycznych. 


\section{BIBLIOGRAFIA}

Al-Khamisy D. (2011), Edukacja integracyjna jako fakt w teorii i praktyce. W: J. Głodkowska (red.), Uczeń ze specjalnymi potrzebami edukacyjnymi w szkole ogólnodostępnej. Wybrane zagadnienia teoretyczne, diagnostyczne i metodyczne, 14-30. Warszawa: Wydawnictwo Akademii Pedagogiki Specjalnej im. Marii Grzegorzewskiej.

Apanel D. (2016), Teoria i praktyka ksztatcenia integracyjnego osób z niepetnosprawnościa w Polsce w latach 1989-2014. Kraków: Oficyna Wydawnicza „Impuls”.

Bar-On, R. (2006). The Bar-On model of emotional-social intelligence (ESI). Psicothema, 18(supl), 13-25.

Brackett M.A., Rivers S.E., Salovey P. (2011), Emotional Intelligence: Implications for Personal, Social, Academic, and Workplace Success. Social and Personality Psychology Compass, 5(1), 88-103.

Cejudo J., López-Delgado M. L., Losada L. (2019), Effectiveness of the videogame „Spock” for the improvement of the emotional intelligence on psychosocial adjustment in adolescents. Computers in Human Behavior, 101, 380-386.

Ciarrochi J., Chan A.Y.C., Bajgar J. (2001), Measuring emotional intelligence in adolescents. Personality and Individual Differences, 31, 1105-1119.

Davis S.K., Humphrey N. (2012), The influence of emotional intelligence (EI) on coping and mental health in adolescence: Divergent roles for trait and ability EI. Journal of Adolescence, 35, 1369-1379.

Extremera N., Fernández-Berrocal P., Salovey P. (2006), Spanish version of the Mayer-Salovey-Caruso Emotional Intelligence Test (MSCEIT). Version 2.0: Reliabilities, age and gender differences. Psicothema, 18, 42-48.

Gajdzica Z. (2011), Sytuacje trudne w opinii nauczycieli klas integracyjnych. Kraków: Oficyna Wydawnicza „Impuls”.

Gardner H., Kornhaber M.L., Wake W.K. (2001), Inteligencja. Wielorakie perspektywy. Warszawa: Wydawnictwa Szkolne i Pedagogiczne.

Garrido B.S. (2012), Inteligencja emocjonalna. Poradnik dla rodziców. Kraków: Wydawnictwo eSPe.

Goleman D. (1997), Inteligencja emocjonalna, thum. A. Jankowski. Poznań: Media Rodzina of Poznań.

Gomez-Baya D., Mendoza R., Paino S., Gaspar de Matos M. (2017), Perceived emotional intelligence as a predictor of depressive symptoms during mid- adolescence: A two-year longitudinal study on gender differences. Personality and Individual Differences, 104, 303-312.

Jaworowska A., Matczak A. (2005), Popularny Kwestionariusz Inteligencji Emocjonalnej. Podręcznik. Warszawa: Pracownia Testów Psychologicznych Polskiego Towarzystwa Psychologicznego.

Kalambouka A., Farrell P., Dyson A., Kaplan I. (2007), The impact of placing pupils with special educational needs in mainstream schools on the achievement of their peers. Educational Research, 49, 4, 365-382.

Knopp K. (2006), Rola inteligencji emocjonalnej w życiu człowieka. Studia Psychologica, 6, 221-235.

Knopp K.A. (2010), Inteligencja emocjonalna oraz możliwości jej rozwijania u dzieci i młodzieży. Warszawa: Wydawnictwo Uniwersytetu Kardynała Stefana Wyszyńskiego.

Lindsay G. (2007), Educational psychology and the effectiveness of inclusive education / mainstreaming. British Journal of Educational Psychology, 77, 1-24.

Lipińska J. (2000), Zaspokajanie potrzeb psychicznych dzieci niepełnosprawnych w klasach integracyjnych. W: A. Rakowska, J. Baran (red.), Dylematy pedagogiki specjalnej, 127-133. Kraków: Wydawnictwo Naukowe Akademii Pedagogicznej.

Malmqvist J. (2016), Working successfully towards inclusion- or excluding pupils? A comparative retroductive study of three similar schools in their work with EBD. Emotional and Behavioural Difficulties, 21, 4, 344-360.

Mancini G., Andrei F., Mazzoni E., Biolcati R., Baldaro B., Trombini E. (2017), Brief report: Trait emotional intelligence, peer nominations, and scholastic achievement in adolescence. Journal of Adolescence, 59, 129-133.

Matczak A., Knopp K. (2013), Znaczenie inteligencji emocjonalnej w funkcjonowaniu człowieka. [Stare Kościeliska]:Wydawnictwo Stowarzyszenia Filomatów. Redakcja Liberi Libri.

Matczak A., Martowska K. (2011), Z badań nad uwarunkowaniami kompetencji emocjonalnych. Studia Psychologica, 11, 1, 5-18.

Matyjas B. (1997), W szkole integracyjnej. Problemy Opiekuńczo-Wychowawcze, 2, 30-31. 
Mayer J.D., Caruso D.R., Salovey P. (1999), Emotional Intelligence Meets Traditional Standards for an Intelligence. Intelligence, 27, 4, 267-298.

Mayer J.D., Caruso D.R., Salovey P. (2016), The Ability Model of Emotional Intelligence: Principles and Updates. Emotion Review, 8, 4, 290-300.

Mayer J.D., Salovey P. (1997), What Is Emotional Intelligence.W: P. Salovey, D.J. Sluyter (eds), Emotional Development and Emotional Intelligence, 3-31. New York: Harper Collins.

Mayer J.D., Salovey P. (1999), Czym jest inteligencja emocjonalna? W: P. Salovey, D.J. Sluyter (red.), Rozwój emocjonalny a inteligencja emocjonalna, 23-69. Poznań: Dom Wydawniczy REBIS.

Michalska P. (2004), Teoretyczne podstawy inteligencji emocjonalnej. W: B. Dyrda (red.), Rozwijanie twórczości i inteligencji emocjonalnej dzieci i młodzieży, 25-40. Kraków: Oficyna Wydawnicza „Impuls”.

Przybylska I. (2007), Inteligencja emocjonalna a uzdolnienia twórcze i funkcjonowanie szkolne młodzieży. Katowice: Wydawnictwo Uniwersytetu Śląskiego.

Przybyła-Basista H. (2000), Inteligencja emocjonalna i możliwości jej rozwijania w szkole. Chowanna, 1, $14,135-143$.

Qualter P., Whiteley H.E., Hutchinson J.M., Pope D.J. (2007), Supporting the Development of Emotional Intelligence Competencies to Ease the Transition from Primary to High School. Educational Psychology in Practice, 23, 1, 79-95.

Ruijs N.M., Peetsma T.T.D. (2009), Effects of inclusion on students with and without special educational needs reviewed. Educational Research Review, 4, 67-79.

Ruijs N.M., Van der Veen I., Peetsma T.T.D. (2010), Inclusive education and students without special educational needs. Educational Research, 52, 4, 351-390.

Saarni C. (1999), Kompetencja emocjonalna i samoregulacja w dzieciństwie. W: P. Salovey, D.J. Sluyter (red.), Rozwój emocjonalny a inteligencja emocjonalna, 75-125. Poznań: Dom Wydawniczy REBIS.

Sadowska M., Brachowicz M. (2008), Struktura inteligencji emocjonalnej. Studia z Psychologii w KUL, 15, 65-79.

Salavera C., Usán P., Jarie L. (2017), Emotional intelligence and social skills on self-efficacy in Secondary Education Students. Are there gender differences? Journal of Adolescence, 60, 39-46.

Salavera C., Usán P., Teruel P. (2019), Contextual problems, emotional intelligence and social skills in Secondary Education students. Gender differences. Annales Médico- Psychologiques, 177, 3, 223-230.

Salovey P., Bedell B.T., Detweiler J.B., Mayer J.D. (2005), Aktualne kierunki w badaniach nad inteligencją emocjonalną. W: M. Lewis, J.M. Haviland-Jones (red.), Psychologia emocji, 634-654. Gdańsk: Gdańskie Wydawnictwo Psychologiczne.

Salovey P., Mayer J.D. (1990), Emotional Intelligence. Imagination, Cognition and Personality, 9, 3, 185-211.

Schutte N.S., Malouff J.M., Hall L.E., Haggerty D.J., Cooper J.T., Golden C.J., Dornheim L. (1998), Development and validation of a measure of emotional intelligence. Personality and Individual Differences, $25,167-177$.

Szumski G. (2011), Teoretyczne implikacje koncepcji edukacji włączającej. W: Z. Gajdzica (red.), Uczeń z niepetnosprawnościq w szkole ogólnodostępnej, 13-23. Sosnowiec: Oficyna Wydawnicza „Humanitas”.

Szumski G., Firkowska-Mankiewicz A. (2010), Is Polish Special Education Effective? Academic and Socioemotional Effects of Schooling in Special, Integrated and Regular Schools. New Educational Review, $20,1,248-260$.

Śmieja M., Orzechowski J. (2008), Inteligencja emocjonalna. Fakty, mity, kontrowersje. W: M. Śmieja, J. Orzechowski (red.), Inteligencja emocjonalna. Fakty, mity, kontrowersje, 19-45. Warszawa: Wydawnictwo Naukowe PWN.

Urbański P., Glapa A., Śleboda R. (2014), Wpływ kształcenia integracyjnego i masowego na stosunek uczniów pełnosprawnych do niepełnosprawności. Niepetnosprawność i Rehabilitacja, 3, 102-121.

Wiącek G., Sękowski A. (2007), Powodzenie w kształceniu integracyjnym a wybrane zmienne psychospołeczne - weryfikacja modelu teoretycznego. Roczniki Psychologiczne, X, 2, 89-111.

Wiśniewska-Juszczak D. (2004), Czy szkoły integracyjne rozwijają kapitał społeczny dzieci? Psychologia Jakości Życia, 3, 1, 39-60.

Zeidner M. (2008), Rozwój inteligencji emocjonalnej. Czego dowiedzieliśmy się do tej pory? W: M. Śmieja, J. Orzechowski (red.), Inteligencja emocjonalna. Fakty, mity, kontrowersje, 82-110. Warszawa: Wydawnictwo Naukowe PWN. 